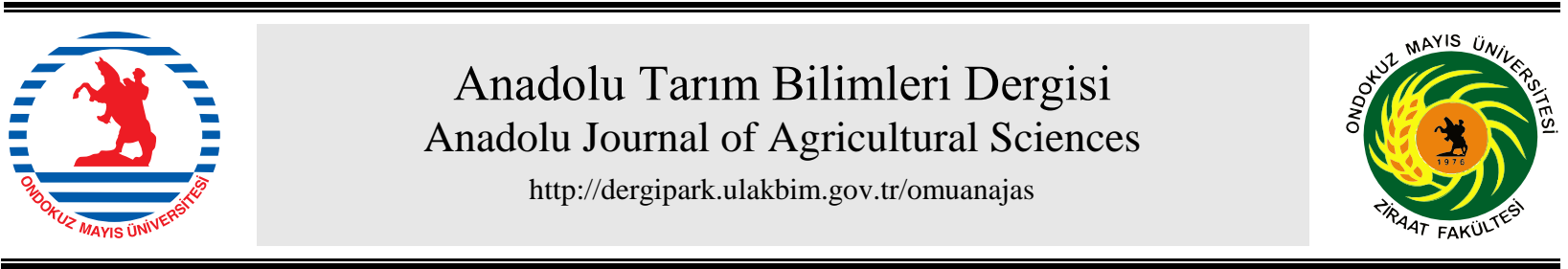

Araştırma/Research

Anadolu Tarım Bilim. Derg./Anadolu J Agr Sci, 31 (2016)

ISSN: 1308-8750 (Print) 1308-8769 (Online) doi: 10.7161/omuanajas.260976

\title{
Organik domates yetiştiriciliğinde ön bitki ve organik gübre uygulamalarına bağlı olarak toprak mikobiyotasındaki değişiklikler
}

\author{
Berna Tunalı $^{a^{*}}$, Gülen Özyazıc1 ${ }^{b}$, Aysun Pekşen ${ }^{c}$

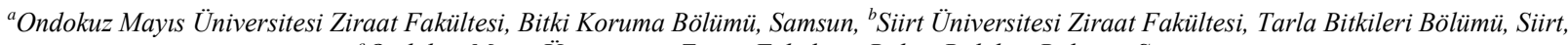 \\ ${ }^{c}$ Ondokuz Mayls Üniversitesi Ziraat Fakültesi, Bahçe Bitkileri Bölümü, Samsun \\ *Sorumlu yazar/corresponding author: btunali@omu.edu.tr
}

Geliş/Received 03/03/2016 Kabul/Accepted 15/06/2016

\begin{abstract}
ÖZET
$\mathrm{Bu}$ araştırma, organik domates üretiminden önce uygulanan ön bitki ve organik gübrelerin topraktaki mikobiyota değişimine etkisinin belirlenmesi amacıyla 2011-2014 yılları arasında yürütülmüştür. Tarla denemeleri, Tesadüf Bloklar deneme deseninde bölünmüş parsellere göre 3 tekrarlamalı olarak kurulmuştur. Araştırmada soğangil, lahanagil ve baklagil+buğdaygillerden üç farklı ön bitki uygulaması (pırasa, brokoli ve fiğ +arpa karışımı) ile kontrol (kışı boş geçiren parsel) ana parsellere, üç farklı organik gübre kaynağ1 (kompost, organik ticari gübre-1 ve organik ticari gübre-2) ise alt parsellere yerleştirilmiştir. Her bir ön bitki ve organik gübre uygulaması sonrası domates hasadından sonra alınan topraklarda tespit edilen fungal mikroorganizma tür ve miktarının başlangıçtakine göre farklı olduğu tespit edilmiştir. Ön bitki ve organik gübre uygulandıktan sonra domates yetiştirilen topraklardaki Penicillium ve Aspergillus cinslerinin sayısının denemenin başlangıcındaki izolat sayısına göre oldukça azaldığı tespit edilmiştir. Fusarium cinsi içinde en yoğun bulunan tür ise $F$. oxysporum olarak bulunmuştur. Denemenin başlangıç yılında ve takiben 2012'de, Pythium ve Rhizoctonia gibi çökerten etmenleri yanında antagonist Acremonium cinsi tespit edilmemişken, 2013 ve 2014 yıllarında bu funguslar gözlenmiştir. Deneme başlangıcına göre toplam patojen ve antagonist mikroorganizma miktarı artmıştır. Ön bitki ve organik gübrelemenin domates yetiştirilen parsellerde Trichoderma ve diğer antagonistik mikroorganizmaların artışı için uygun şartları oluşturduğu anlaşılmaktadır. Toprak mikobiyotasının bitkilerdeki hastalıklar üzerine etkileri hakkında detaylı çalışmalar yapılması uygun olacaktır.
\end{abstract}

Changes in soil mycobiota in response to previous crop and organic fertilizer applications in organic tomato cultivation

\begin{abstract}
This study was conducted to determine the effects of the previous crop and organic fertilizer applications prior to tomato production on changes in soil fungal communities between 2011 and 2014. Field experiments were established according to Split Plots in Randomized Complete Block Design (RCBD) with three replications. In the study, three previous crop treatments from Alliaceae, Cruciferae, Fabaceae+Gramineae families (leek, broccoli and vetch+barley mixture) and control (no previous crop during winter season) were placed in the main plots whereas three different fertilizer sources (compost, organic commercial fertilizer-1 and organic commercial fertilizer-2) were placed in the sub-plots. It was determined that fungal microorganism species and their numbers determined in the soil samples taken after tomato harvest following each previous crop and fertilizer applications were different from the initial fungal microorganism profile and number. The numbers of isolates belonging to Penicillium and Aspergillus genera in tomato-grown soils after the previous crop and organic fertilizer applications decreased when compared with the number of initial isolates at the beginning of the experiment. $F$. oxysporum was found as the most prevalent species in Fusarium genus. While damping-off pathogens, Pythium and Rhizoctonia, and antagonist Acremonium were not observed in the beginning and 2012, they were detected in 2013 and 2014 years. Antagonist and pathogenic microbial community increased, compared to pre-sowing season. It was thought that the previous crop and organic fertilization applications created favorable conditions for the development of Trichoderma and other antagonistic organisms in tomato-grown plots. It can be useful to conduct more detailed studies on the impacts of soil mycobiota on plant diseases.
\end{abstract}

Anahtar Sözcükler:

Domates

Ekim nöbeti

Fungus

Organik gübre

Organik tarım

Ön bitki

Solanum lycopersicum

Keywords:

Tomato

Rotation

Fungi

Organic fertilizer

Organic agriculture

Previous crop

Solanum lycopersicum 


\section{Giriş}

Organik tarım; üretimde sentetik kimyasal girdi ve ilaç kullanmadan yönetmelikler çerçevesinde izin verilen girdilerin kullanımı ile yapılan, üretimden tüketime kadar her aşaması kontrollü ve sertifikalı tarımsal üretim biçimidir. Konvansiyonel tarımda verimde artı̧̧ sağlanmasına karşın toprağın yapısının bozulması, su kirliliği ve bazı pestisitlere direnç sağlanması gibi önemli çevre sorunları söz konusudur. Hatalı uygulamalar sonucunda yapısı bozulan toprağın iyileştirilmesi ve içindeki mikroorganizmaların korunup gelişiminin sağlanması, toprağın tek yönlü sömürülmesinin önlenerek doğal verimliliğinin devam ettirilmesi organik tarımın ana ilkelerdendir.

Organik tarımda, toprağın biyolojik yapısının, canlılı̆̆ının korunması, toprak verimliliğinin sürdürülebilirliğinin sağlanması temel koşuldur. Bunun sağlanabilmesi amaciyla da organik gübre ve bazı toprak düzenleyicilerin kullanılması zorunlu hale gelmiştir. Organik gübrelerin üretimi ve kullanımı gün geçtikçe artmaktadır. Organik gübreler organik madde, mikroorganizmalar ve bitki besin maddeleri içermeleri nedeniyle toprakların fiziksel, kimyasal ve biyolojik özelliklerini iyileştirmekte ve toprak verimliliğinin devamını sağlamaktadır.

Organik tarımın vazgeçilmez unsurlarından biri de ekim nöbetidir ve organik tarım sisteminin başarısını büyük ölçüde etkilemektedir. Hastalık etmenlerinin çoğu bir konukçuya veya aynı cins veya familya içerisinde yer alan birden çok konukçuya özelleşmiş bulunmaktadır. Bazı mikorizalar, endofitik funguslar ve patojenlerin konukçuya özelleştiği de bilinmektedir (Zhou ve Hyde, 2002). Birçok hastalık etmeni aynı tarlaya üst üste aynı ürünün ekilmesiyle ciddi sorunlar yaratmaktadır. Uygun bir ekim nöbeti toprakta besin miktarlarının artmasının yanı sıra toprakta hastalık ve zararlı populasyonunu da azaltarak bitki gelişimi ve verimi üzerine önemli faydalar sağlamaktadır (Lamey ve Diaper, 1992). Özellikle Fusarium türlerine karşı en etkili mücadele yollarından biri ekim nöbetidir. Etkili bir ekim nöbeti için iyi bir planlama yapılması ve doğru uygulanması büyük önem taşımaktadır. İyi planlanmış ekim nöbeti sistemlerinde toprak yapısı gelişmekte, toprakların azot ve organik madde içeriği artmakta, topraktaki bitki besin maddeleri ve uygulanan gübreler daha etkin bir şekilde değerlendirilebilmekte ve bunların yanı sira hastalıklar azalmakta, yabanc1 ot ve zararlı kontrolü kolaylaşmaktadır (Duman ve Algan, 2012).

Turhan ve ark. (2007), bazı lahana grubu sebzelerden (brokoli, karnabahar ve lahana) sonra yetiştirilen yazlık bitkilerde (domates, biber ve patlıcan) toprak kaynaklı fungal hastalıkların oluşumu ve bitkilerin gelişimini incelemişlerdir. Çalışmada en yüksek verim domates ve patlicanda lahana ve brokoli ön bitki parsellerinde elde edilmiş, buna karşılık biberde verim değerleri üzerine lahanagil münavebesinin olumlu etki yapmadığı tespit edilmiştir. Denemelerin yürütüldüğü 2 yıl içerisinde yazlık sebzelerin kontrol parsellerinde bile önemli kök hastalığı çıkışı olmadığ için lahanagil artıklarının etkisi hakkında kesin bir kanıya ulaşılamamıştır. Smith ve Collins (2007), ekim nöbetinin ve bitki türünün, mikrobiyal dağılıma ve enzim aktivitesine etkisinin, toprak tipi ve gübreleme ile ilişkili olarak çok farklılıklar gösterdiğini bildirmişlerdir.

Suzuki ve ark. (2012), ekim nöbeti ve zamanlamanın topraktaki mikobiyotanın değişiminde etkili olduğunu belirtmişlerdir. Ancak organik sebze tarımında ana ürün için ekim nöbetinde kullanılan ön bitki ve organik gübrelerin topraktaki patojen ve antagonistler üzerindeki etkisi konusunda da yeterli çalışma bulunmamaktadır.

$\mathrm{Bu}$ çalışmanın amacı; organik sebze tarımında açıkta ana ürün olarak yetiştirilen domates yetiştiriciliğinden önce uygulanan farklı ön bitki ve organik gübrelerin topraktaki mikobiyota üzerine etkisini saptamaktır.

\section{Materyal ve Metot}

Çalışma, Karadeniz Tarımsal Araştırma Enstitüsü'ne ait Bafra Deneme İstasyonu arazisinde 4 yll süre ile (2011-2014) yürütülmüştür. Deneme yeri topraklarında yapılan toprak analiz sonuçlarına göre killi bünyeye sahip, hafif alkali, tuzsuz, organik madde kapsamları orta, kireç kapsamları kireçli ve orta kireçli, fosfor kapsamları 2012 ve 2013 y1llarında orta, 2014 yilında yüksek seviyede bulunmuştur. Toprakların potasyum içeriklerinin de yüksek olduğu tespit edilmiştir.

\subsection{Materyal}

Çalışmada Rio Grande domates çeşidi kullanılmıştır. Ön bitki olarak kullanılan pırasa türünde İnegöl 92, brokoli türünde Belstar $F_{1}$ ile fiğ +arpa karışımında fĭg olarak Kubilay-82, arpa olarak Akhisar 98 çeşitleri kullanılmıştır. Organik gübre kaynakları olarak kompost, organik ticari gübre-1 ve organik ticari gübre2 (Biofarm) kullanılmıştır. Kompost, organik büyükbaş hayvan gübresi ve tavuk gübresinin kompostlanmış halidir. Organik gübre kaynaklarının içerikleri Çizelge 1 'de verilmiştir.

Çizelge 1. Organik gübre kaynaklarının bazı kimyasal özellikleri

\begin{tabular}{llllllll}
\hline $\begin{array}{l}\text { Organik gübre } \\
\text { kaynaklar1 }\end{array}$ & $\mathrm{pH}$ & $\begin{array}{l}\text { Organik madde } \\
(\%)\end{array}$ & $\begin{array}{l}\text { Organik C } \\
(\%)\end{array}$ & $\begin{array}{l}\text { Toplam N } \\
(\%)\end{array}$ & $\mathrm{C} / \mathrm{N}$ & $\begin{array}{l}\mathrm{P}_{2} \mathrm{O}_{5} \\
(\%)\end{array}$ & $\begin{array}{l}\mathrm{K}_{2} \mathrm{O} \\
(\%)\end{array}$ \\
\hline & 7.9 & 45 & 26.16 & 2.81 & 9.31 & 2.60 & 1.42 \\
Organik ticari gübre-1 & 7.5 & 40 & 23.25 & 1.97 & 11.80 & 1.00 & 1.50 \\
Organik ticari gübre-2 & 7.0 & 65 & 37.79 & 3.50 & 10.80 & 3.00 & 3.00 \\
\hline
\end{tabular}




\section{2. Ön bitki ve organik gübre uygulamalart}

Çalışma, Tesadüf Bloklarında bölünmüş parseller deneme desenine göre 3 tekerrürlü ve ana parsellerde üç farklı ön bitki (pırasa, brokoli, fĭğ+arpa karışımı) ile kontrol (kışı boş geçiren), alt parsellerde ise üç farklı organik gübre kaynağ 1 (kompost, organik ticari gübre-1 ve organik ticari gübre-2) olacak şekilde planlanmıştır.

Ön bitkiler ekim ve dikiminden önce deneme alanında buğday yetiştirilmiş, buğday hasadından sonra arazi pullukla sürülerek kazayağı çekilmiş ve tırmıklanarak hazır hale getirilmiştir. Pırasa tohumları mayıs ayında fideliklere ekilmiş, temmuz ayının ikinci yarısında sıra arası $25 \mathrm{~cm}$, sira üzeri $10 \mathrm{~cm}$ olacak şekilde araziye şaşırtılmıştır. Brokoli tohumları temmuz ayında viyollere ekilerek önce fideleri elde edilmiş, daha sonra fideler ağustos ayının ikinci yarısında tarlaya sıra arası ve sıra üzeri $50 \mathrm{~cm}$ olacak şekilde şaşırtılmıştır. Fiğ + arpa karışımı $\% 75$ fĭğ, \%25 arpa (3:1) oranında olacak şekilde fiğin tohumluk miktarı dikkate alınarak 9:3 kg.da ${ }^{-1}$ olarak kasım ayının ilk haftası ekilmiştir. Brokoli ve pırasa bitkileri yağmurlama sulama yöntemi ile domates bitkisinin sulanmasında ise damla sulama yöntemi kullanılmıștır. Fi ğ +arpa karıșımı, fiğin \%30 çiçeklenme döneminde biçilerek toprağa karıştırılmıştır. Brokoli ve pırasa bitkileri hasat olgunluğuna geldiğinde birkaç defa hasat edilerek hasatlar tamamlanmıştır. Domates denemelerinde kenarlardan birer sıra, parsel başı ve sonlarından birer sıra bitki kenar tesiri olarak atılmıştır. Hasat olgunluğuna gelen bitkiler elle kesilmek ya da sökülmek suretiyle hasat işlemi yapılmıştır.

\subsection{Toprakta mikobiyotanın tespiti}

Toprakta başlangıçtaki mikobiyotayı tespit etmek amacıyla deneme alanında buğday hasadından sonra ön bitkilerin ekim ve dikiminden önce 2011 Temmuz ayında toprak örneklemesi yapılmıştır. Çalışmada, buğday hasadı ile ön bitki yetiştiriciliği ve organik gübre uygulaması yapıldıktan sonra organik domates yetiștiriciliği yapılmıştır. Her üç deneme yılında (2012, 2013 ve 2014 yıllarında) da toprak örnekleri, domates hasadından sonra eylül ayının ilk haftası her bir uygulama için ayrı ayrı olacak şekilde alınmıştır. Denemede tüm parseller ve tekerrürlere gidilerek her parselin 3 noktasından $20 \mathrm{~cm}$ derinlikten olacak şekilde toprak sondası ile en az $1.5 \mathrm{~kg}$ toprak örneği alınarak iklim odasına getirilmiştir. Topraktaki mikobiyotanın belirlenmesi çalışmalarına kadar iklim odasında tutulmuştur.

Getirilen topraklar önce serilerek 7-10 gün süreyle iklim odasında kurutulmuş, kurutulan topraklar dövülerek toz haline getirilmiştir (Dhingra ve Singlair, 1995). Paçal yapılan topraklardan 3 tekrarlamalı olarak 10 'ar gram alınmış ve $30{ }^{\circ} \mathrm{C}$ 'de inkübatörde tekrar kurutulmuştur. Bu toprak örneğinden $1 \mathrm{~g}$ alınarak 500 $\mathrm{ml}$ su içerisinde karıştırıcıda karıştırılmıştır. Bu süspansiyondan $1 \mathrm{ml}$ 'si, \%2'lik su agarı (SA) bulunan 9 cm'lik petrilere yayılmıştır. Bu uygulama 3 tekerrürlü olarak yapılmıştır (Eyjolfsdottir, 1995). İkinci günden itibaren gelişen koloniler incelenerek farklı görünümde olanlar bakterisit (oxytetracyline ve streptomycin sulfate) ilave edilen patates dekstroz agar (PDA) ve sentetik besin ortamı (SNA)'na aktarılmıștır. 5-8 gün sürelerle $23^{\circ} \mathrm{C}$ 'de 12 saat $1 s ̧ \mathrm{k} / 12$ saat karanlık koşullara ayarlanan inkübatörde inkübasyona bırakılmıştır. Gelişen fungus kültürleri stereomikroskop ve 1 şı mikroskobu altında incelenerek teşhisleri Gerlach ve Nirenberg (1982), Dick (1990), Barnett ve Hunter (1998), Lessie ve Summerell (2006)'ya göre yapılmıştır. Saf olarak gelişen funguslar cryoviollere alınarak derin dondurucuda $\left(-85^{\circ} \mathrm{C}\right)$ saklanmıştır.

\section{Bulgular ve Tartışma}

Organik domates üretiminden önce farklı ön bitki ve organik gübre uygulamalarının domates yetiştirilen alanlardaki mikobiyota üzerine etkisinin belirlenmesine yönelik yapılan çalışmada, buğday hasadından sonra 2011 Temmuz ayında alınan toprak örneklerinde deneme alanının başlangıç mikobiyotası tespit edilmiştir. Koloni sayısı bakımından incelendiğinde Penicillium cinsinin koloni sayısının diğer cinslere göre oldukça yüksek olduğu saptanmıştır (Çizelge 2). Wakelin ve ark. (2007), Penicillium spp.'nin toprakta bulunuş bakımından en yaygın fungusların başında geldiğini bildirmektedirler. Topraklarda en baskın ve yaygın bulunan cinsin Penicillium olduğunu bildiren Azaz ve Hasenekoğlu (1997), Asan (2004), Oskay (2007) ve Wakelin ve ark. (2007)'in bulgulariyla bu çalışma sonuçlarının benzer olduğu görülmektedir. Penicillium cinsini Aspergillus, Sclerotium ve Fusarium cinsleri izlemiştir. Fusarium cinsi içinde teşhisleri yapılan türler $F$. graminearum, $F$. solani, $F$. proliferatum ve $F$. verticillioides türleridir.

Çizelge 2. Başlangıçtaki deneme alanında belirlenen fungus cinsleri ve koloni sayıları

\begin{tabular}{lc}
\hline Fungal cinsler & $\begin{array}{r}\text { Koloni say1s1 } \\
\left(5 \times 10^{2}\right)\end{array}$ \\
\hline Penicillium spp. & 95.33 \\
Fusarium spp. & 4.64 \\
Aspergillus spp. & 10.99 \\
Gleocladium spp. & 0.66 \\
Sclerotium spp. & 8.99 \\
Cladosporium spp. & 0.33 \\
Stemphylium spp. & 0.33 \\
Epicoccum spp. & 0.33 \\
Trichoderma spp. & 3.33 \\
Mucor spp. & 0.33 \\
\hline
\end{tabular}

Deneme yillarına ait her domates hasat döneminden sonra alınan toprak örneklerinde tespit edilen fungus cinsleri ve koloni sayıları Çizelge 3'de verilmiştir. 
Çizelge 3. Deneme alanlarından yıllara göre izole edilen fungus cinsleri ve koloni sayıları $\left(5 \times 10^{2}\right)$

\begin{tabular}{|c|c|c|c|c|c|c|c|c|c|c|c|c|}
\hline Cinsler & PK & PO-2 & PO-1 & BK & BO-2 & BO-1 & FAK & FAO-2 & FAO-1 & KK & KO-2 & KO-1 \\
\hline \multicolumn{13}{|c|}{2012} \\
\hline Penicillium spp. & 5.00 & 8.67 & 4.33 & 5.67 & 4.33 & 7.33 & 7.67 & 6.67 & 3.00 & 3.67 & 3.00 & 2.67 \\
\hline Aspergillus spp. & - & - & - & - & 0.67 & 0.33 & 1.33 & - & - & - & - & - \\
\hline Trichoderma spp. & - & - & - & - & - & - & - & 0.33 & - & - & - & 0.33 \\
\hline Fusarium spp. & - & - & 1.33 & 0.33 & - & - & 0.33 & 0.33 & - & - & - & - \\
\hline Verticillium spp. & - & - & - & 0.33 & - & - & - & - & - & - & - & - \\
\hline Trichothecium spp. & - & - & - & - & - & - & - & - & - & - & 0.33 & - \\
\hline Sclerotinium spp. & - & - & - & - & - & - & - & - & - & - & 0.33 & - \\
\hline Cladosporium spp. & - & - & - & - & - & - & 0.33 & - & - & - & - & - \\
\hline Stemphylium spp. & - & - & - & - & - & - & - & 0.33 & - & - & - & - \\
\hline Alternaria spp. & 0.33 & - & - & - & - & - & - & - & - & - & - & - \\
\hline \multicolumn{13}{|c|}{2013} \\
\hline Penicillium spp. & 2.33 & 0.67 & 1.67 & 3.00 & 2.67 & 2.67 & 3.33 & 1.67 & 7.67 & 1.67 & 2.00 & 2.67 \\
\hline Aspergillus spp. & 2.00 & - & 1.33 & 0.33 & 2.34 & 0.33 & - & 1.66 & 1.67 & 1.00 & 0.67 & 0.33 \\
\hline Trichoderma spp. & - & 1.33 & 2.00 & 0.33 & 1.00 & 2.00 & 2.67 & 3.33 & 1.33 & 2.00 & 1.33 & 3.67 \\
\hline Fusarium spp. & 3.67 & 2.67 & 1.67 & 2.33 & 3.33 & 4.33 & 3.00 & 0.67 & 1.67 & 3.00 & 3.33 & 2.33 \\
\hline Acremonium spp. & - & - & 1.67 & - & - & - & - & - & - & - & - & - \\
\hline Verticillium spp. & 0.67 & - & - & - & - & - & 1.33 & - & - & 0.33 & - & - \\
\hline Botryoderma spp. & 0.33 & - & - & - & - & - & - & - & - & - & - & - \\
\hline Pythium spp. & 0.33 & - & - & - & - & - & - & - & - & - & - & - \\
\hline Rhizoctonia spp. & - & 0.67 & - & - & - & - & - & - & - & - & 0.33 & - \\
\hline Geotricum spp. & - & - & - & - & - & - & - & - & - & - & - & 2 \\
\hline Mucor spp. & 0.67 & 0.67 & - & 1.33 & - & - & - & - & 0.33 & 1 & 0.67 & - \\
\hline \multicolumn{13}{|c|}{2014} \\
\hline Penicillium spp. & 0.33 & 0.67 & 0.33 & - & 1.00 & 0.67 & 0.33 & 1.33 & 0.33 & 1.67 & 1.00 & 1.33 \\
\hline Aspergillus spp. & 1.00 & 0.67 & 0.33 & 1.67 & 0.33 & - & 0.67 & - & 0.66 & 0.33 & 1.00 & 1.33 \\
\hline Trichoderma spp. & 0.33 & - & 0.33 & - & 2.33 & - & 0.67 & 0.33 & 0.33 & 0.33 & 1.00 & 0.67 \\
\hline Fusarium spp. & - & 0.66 & 0.66 & 0.33 & 0.66 & 0.67 & - & 0.66 & - & - & 0.33 & 1.65 \\
\hline Acremonium spp. & - & - & - & - & - & 0.33 & - & - & - & - & - & - \\
\hline Verticillium spp. & 0.33 & 0.33 & - & - & - & - & - & - & - & - & - & - \\
\hline Phoma spp. & - & - & - & 0.67 & - & - & 0.33 & 0.33 & - & - & - & - \\
\hline Cylindrocarpon spp. & - & - & 0.33 & - & - & - & - & - & - & - & - & - \\
\hline Phytium spp. & - & - & 0.33 & - & - & - & - & - & - & - & - & - \\
\hline Muсоr spp. & 0.67 & 0.67 & 1.00 & 1.67 & 1.00 & 1.67 & 0.67 & 0.33 & 1.00 & - & 1.33 & 1.00 \\
\hline
\end{tabular}

PK=Pırasa-kompost, PO-2=Pırasa-organik ticari gübre-2, PO-1=Pırasa-organik ticari gübre-1, BK=Brokoli-kompost, BO2=Brokoli-organik ticari gübre-2, BO-1=Brokoli-organik ticari gübre-1, FAK=Fĭg +arpa-kompost, FAO-2=Fiğ+arpa-organik ticari gübre-2, FAO-1=Fiğ+arpa-organik ticari gübre-1, KK=Kontrol-kompost, KO-2=Kontrol-organik ticari gübre-2, KO$1=$ Kontrol-organik ticari gübre-1

Her bir ön bitki (pırasa, brokoli, fiğğarpa karışımı ve kontrol) ve organik gübre (kompost, organik 1 ve 2) uygulamasında tespit edilen fungus tür ve miktarının farklı olduğu tespit edilmiştir.

Ön bitki ve organik gübre uygulandıktan sonra domates yetiştirilen topraklardaki Penicillium ve Aspergillus cinslerinin sayısının başlangıca göre oldukça azaldığı saptanmıştır. Başlangıçta toprakta bulunan Sclerotium cinsi 2012, 2013 ve 2014 yillarında deneme alanında tespit edilmemiştir. Buna karşıllı başlangıçta ve 2012 yılında deneme alanında tespit edilmemiş olan Pythium (2013 ve 2014 yılları) ve Rhizoctonia (2013 y1lı) gibi çökerten etmenleri saptanmıştır. Denemenin ikinci ve üçüncü yılında ise farklı olarak antagonist funguslardan Acremonium cinsi belirlenmiştir (Çizelge 3).

Deneme alanında yıllara göre Fusarium türlerinin dağglımı incelendiğinde, 2012 yılında farklı ön bitki ve organik gübre uygulamalarından sonra domates yetiştirilen alanlardaki Fusarium miktarının başlangıca göre azaldığı görülmektedir. Buna karşılık 2013 yılında alınan toprak örneklerinde Fusarium miktarında ciddi artış meydana geldiği belirlenmiştir (Şekil 1 ve 2). Bu durumun konukçu ile patojen Fusarium spp. arasındaki hastalık ilişkisinden kaynaklanabileceği düşünülmektedir. Samsun yöresinde yapılan bir çalışmada Fusarium'un domateste toprak patojenleri arasında en yaygın patojen olduğu ve funguslar arasında bulunma oranının 2005 yılında \%87.1 ve 2006 yilında \%91.8 olduğu bildirilmiştir (Erol ve Tunal1, 2009). 2014 yılında farklı ön bitki ve organik gübre uygulamalarından sonra domates yetiştirilen alanlardaki Fusarium miktarının 2013 yılına göre tekrar azaldığ saptanmıştır. Özellikle, brokoli-kompost (BK) uygulamas1 haricinde, diğer ön bitki ve kompost uygulamalarında [pırasa-kompost (PK), fiğg+arpakompost (FAK) ve kontrol-kompost (KK)] Fusarium spp.'e rastlanmamıştır (Çizelge 3 ve Şekil 1). Cheuk ve ark. (2005), F. oxysporum radicis-lycopersici'nin tavuk gübresinden hazırlanan kompostlarda bask1 altına alındığını bildirmişlerdir.

Deneme yıllarında yapılan morfolojik tür teşhislerinde Fusarium cinsine ait izolatlar içinde $F$. solani, $F$. oxysporum $F$. subglutinans, $F$. proliferatum, $F$. semitectum, $F$. javanicum ve $F$. acuminatum türleri tespit edilmiştir. Bu çalışmada, Fusarium cinsi içinde en 
• Başlangıç $\square 2012 \square 2013 \square 2014$

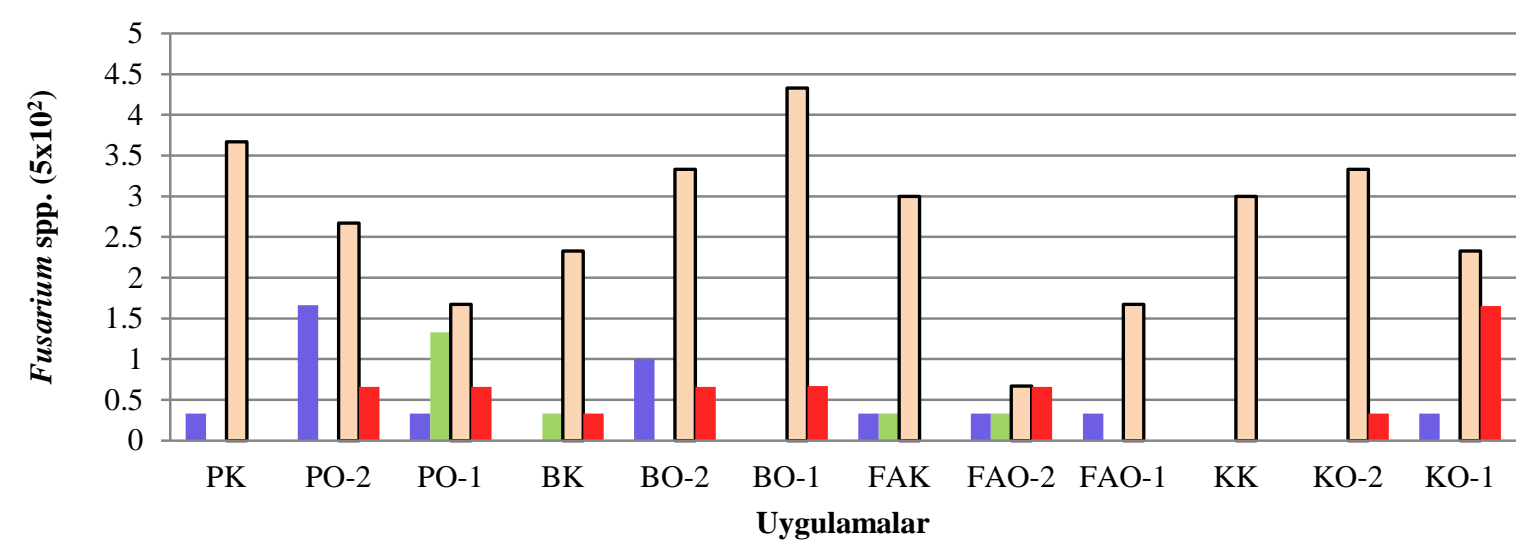

Şekil 1. 2011-2014 yılları arasında organik domates üretimi sonrası farklı ön bitki ve organik gübre uygulamalarına ait parsellerden alınan toprak örneklerindeki Fusarium spp. miktarı (PK=Pırasa-kompost, PO-2=Pırasa-organik ticari gübre-2, PO-1=Pırasa-organik ticari gübre-1, BK=Brokoli-kompost, BO-2=Brokoli-organik ticari gübre-2, BO-1=Brokoli-organik

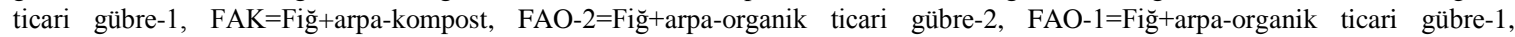
$\mathrm{KK}=$ Kontrol-kompost, KO-2=Kontrol-organik ticari gübre-2, KO-1=Kontrol-organik ticari gübre-1)

yoğun bulunan türün $F$. oxysporum olduğu belirlenmiştir. Elde ettiğimiz bu bulguların domateslerde $F$. oxysporum türünün hem köklerde hem de rizosferde en yaygın patojen fungus olduğunu bildiren Swer ve ark. (2011)'in bulgulariyla uyumlu olduğu görülmektedir. Yapılan bir başka çalışmada ise $F$. oxysporum'un toprakta bulunma miktarı ile bitki köklerinde bulunma miktarı arasında doğru oranda bir ilişki olduğu, ancak organik topraklarda $F$. oxysporum'un bitkiye kolonizasyonunun konvansiyonel tarım alanlarına oranla daha az olduğu bildirilmiştir (Wu ve ark., 2008).

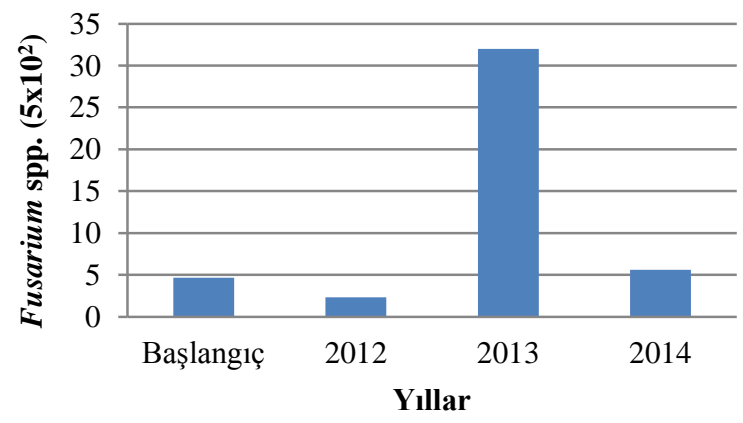

Şekil 2. Deneme alanında yıllara göre Fusarium spp. miktar1

$\mathrm{Bu}$ araştırma alanı Karadeniz Tarımsal Araştırma Enstitüsü'nün Bafra Deneme istasyonunda organik tarıma ayrılmış sertifikalı parsellerinde kurulmuştur. Deneme kurulmadan önce buğday hasadından sonra 2011 yılının Temmuz ayında alınan toprak örneklerinde Trichoderma cinsine rastlanmıştır (Çizelge 3). Bununla birlikte 2012 yılında ön bitki ve organik gübre uygulanan alanda domates yetiştiriciliğinden sonra alınan toprak örneklerinde fiğ + arpa-organik ticari gübre-2 (FAO-2) ve kontrol-organik ticari gübre-1 (KO1) uygulamaları dışında diğer uygulamalarda Trichoderma cinsi tespit edilmemiştir. Buna karşılık 2013 yılında Trichoderma türlerinde ciddi oranlarda artış olduğu görülmektedir (Çizelge 3, Şekil 3 ve 4). Kök salgıları fungusların rizosfer toprağındaki dağılım ve aktivitelerinde önemli rol oynamaktadır (Singh ve ark., 1980). 2014 yilında tespit edilen Trichoderma cinsi miktarı 2013 yılına göre az olmakla birlikte, diğer y1llara göre yüksek bulunmuştur (Şekil 4).

FAK ve KO-1 uygulamasina ait parsellerden başlangıçta alınan toprak örneklerinde saprofitik funguslar dişında antagonist veya patojenik olabilecek funguslar tespit edilememiştir. Başlangıçta diğer parsellerde de patojen mikroorganizma miktarlarının antagonist mikroorganizma miktarından yüksek olduğu görülmektedir (Şekil 5).

2012 yılında ise sadece KO-1 uygulamasında antagonist mikroorganizma miktarında önemli artışlar olduğu görülmektedir. 2013 yılında da FAO-2, pırasaorganik ticari gübre-1 (PO-1) ve KO-1 uygulamalarında antagonist mikroorganizma miktarı yüksek bulunurken, diğer uygulamalarda patojen mikroorganizma miktarı yüksek bulunmuştur. Brokoli-organik ticari gübre-2 (BO-2), FAK, fiğ +arpa-organik ticari gübre-1 (FAO-1), $\mathrm{KK}$ ve kompost-organik ticari gübre-2 (KO-2) uygulamalarında 2014 yılında antagonist miktarının yüksek olduğu saptanmıştır. $\mathrm{Bu}$ uygulamalarda antagonist mikroorganizma miktarı artarken patojen miktarının azaldığı veya hiç saptanmadığı görülmektedir (Şekil 5). Serra-Wittling ve ark. (1996) antagonist mikroorganizmalardan Trichoderma, Paecilomyces ve Gliocladium spp.'nin organik tarım yapılan tarlalarda arttı̆̆ını, buna karşılık patojen olduğu bilinen Pythium, Phytophtora ve Fusarium spp.'nin 


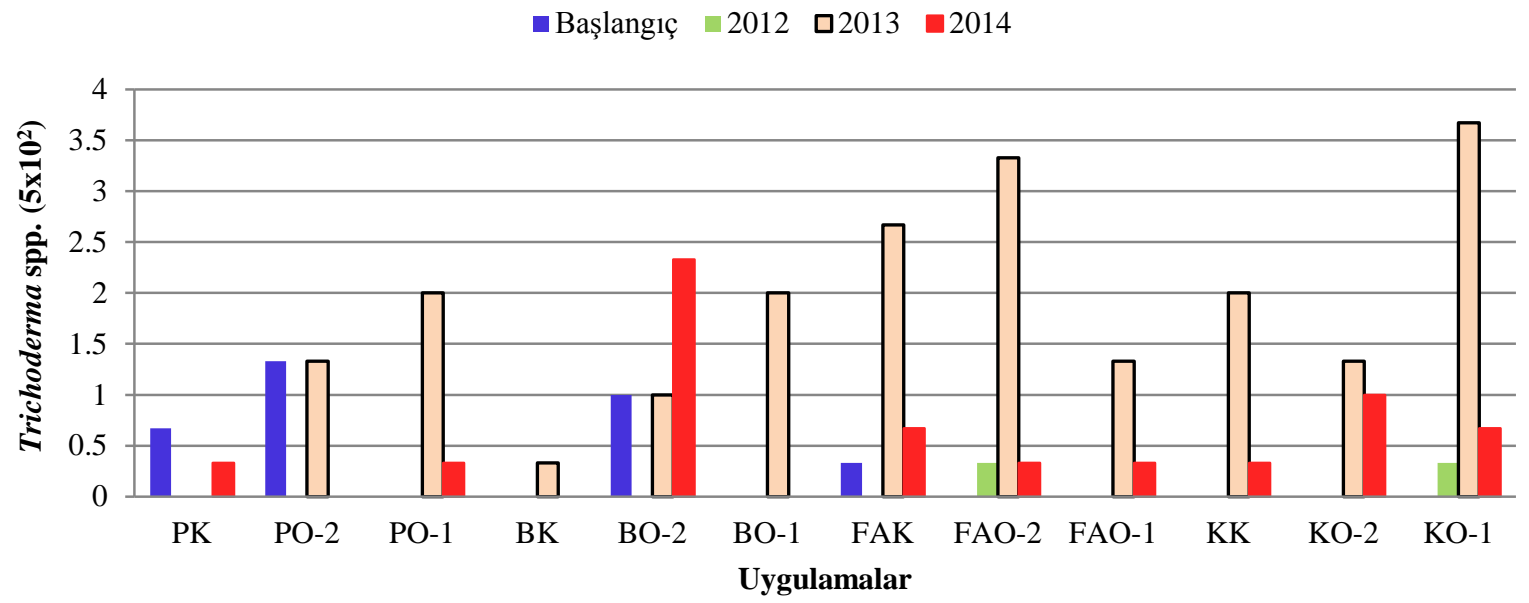

Şekil 3. 2011-2014 yılları arasında organik domates üretimi sonrası farklı ön bitki ve organik gübre uygulamalarına ait parsellerden alınan toprak örneklerindeki Trichoderma spp. miktarı (PK=Pırasa-kompost, $\mathrm{PO}-2=$ Pırasa-organik ticari gübre-2, PO-1=Prrasa-organik ticari gübre-1, BK=Brokoli-kompost, BO-2=Brokoli-organik ticari gübre-2, BO-1=Brokoliorganik ticari gübre-1, FAK=Fiğ+arpa-kompost, FAO-2=Fiğ+arpa-organik ticari gübre-2, FAO-1=Fiğ+arpa-organik ticari gübre-1, $\mathrm{KK}=$ Kontrol-kompost, $\mathrm{KO}-2=$ Kontrol-organik ticari gübre-2, $\mathrm{KO}-1=$ Kontrol-organik ticari gübre-1)

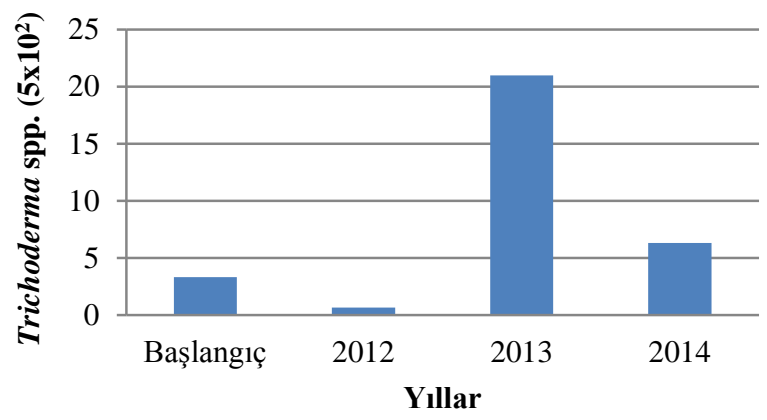

Şekil 4. Deneme alanında yıllara göre Trichoderma spp.'nin miktarı

azaldığını bildirmektedirler. Organik ve sentetik gübrelemenin organik ve konvansiyonel tarım yapılan tarlalarda mikobiyatanın etkisi üzerine yapılan bir araştırmada, organik gübreleme yapılan parsellerde Trichoderma türlerinde önemli artış olurken aynı parsellerde Pythium ve Phytophthora miktarında konvansiyonel tarım yapılan parsellere oranla azalma olduğu ve Fusarium miktarında ise bir farklılık oluşmadığı belirlenmiş̧tir (Bulluck ve ark., 2002).

Her bir ön bitki (pırasa, brokoli, fï̆ +arpa karışımı ve kontrol) ve organik gübre (kompost, organik 1 ve 2) uygulamasından sonra domates yetiştirilen toprak örneklerindeki patojen ve antagonist tür ve miktarlarının farklı olduğu görülmektedir (Şekil 5). Mills ve ark. (2002), Solanaceae bitkilerinde Phytophtora capsici ve Septoria lycopersici'nin kompost uygulanan tarlalarda azaldığıı Rhizoctonia solani ve Streptomyces scabies'in enfeksiyon şiddetinin çiftlik gübresi uygulanan tarlalarda azaldığı ortaya konulmuştur (Tsror-Lakhim ve ark., 2001; Lazarovits ve ark., 2008). CwalinaAmbroziak ve Wrzbowska (2009) çiftlik gübresi uygulaması yapıldığında patojen miktarında azalma olduğunu, çiftlik gübresi miktarının 2 katına çıkınca azalmanın büyük miktarlara ulaştığını bildirmişlerdir. Aynı araştırıcılar, vermikompost uygulamasının patojen olmayan saprofit özellikli funguslardan Aspergillus ve Penicillium oranlarında bir artışa neden olduğunu belirtmişlerdir.

Deneme başlangıcı ve yıllara göre toprak örneklerindeki toplam patojen ve antagonist mikroorganizma miktarları incelendiğinde başlangıca göre hem patojen hem de antagonist mikroorganizma miktarı artmıştır. Antagonist mikroorganizma miktarı denemenin 2012 ve 2013 y1llarında patojen mikroorganizma miktarından düşük bulunurken, 2014 yılında benzer seviyelerde bulunmuştur (Şekil 6). Uygulamaların birçoğunda hem patojen hem de antagonisit mikroorganizma miktarları 2013 yılında diğer yıllara göre bir hayli yüksek bulunmuştur. Abawi ve Widmer (2000) organik gübrelerin uygulandığ1 organik tarım topraklarında patojenik fungusların ve antagonistik organizmaların artı̧̧ gösterdiğini, ancak patojenlerin bitkilerde önemli sayılabilecek hastalıklara yol açamadıklarını ve antagonist organizmaların da hastalıkların baskı altında tutulmasını sağladıklarını bildirmişlerdir. Elde ettiğimiz sonuçlar Abawi ve Widmer (2000)'in sonuçları ile uyumludur.

\section{Sonuç}

Topraktaki fungal floraya etki eden birçok faktör vardır. Bunların başında iklimsel faktörler, bitki deseni, tarımsal faaliyetler, toprak işleme metotları vs. gelmektedir. Bu çalışmada ön bitki ve organik gübre uygulamalarının organik domates tarımı yapılan 

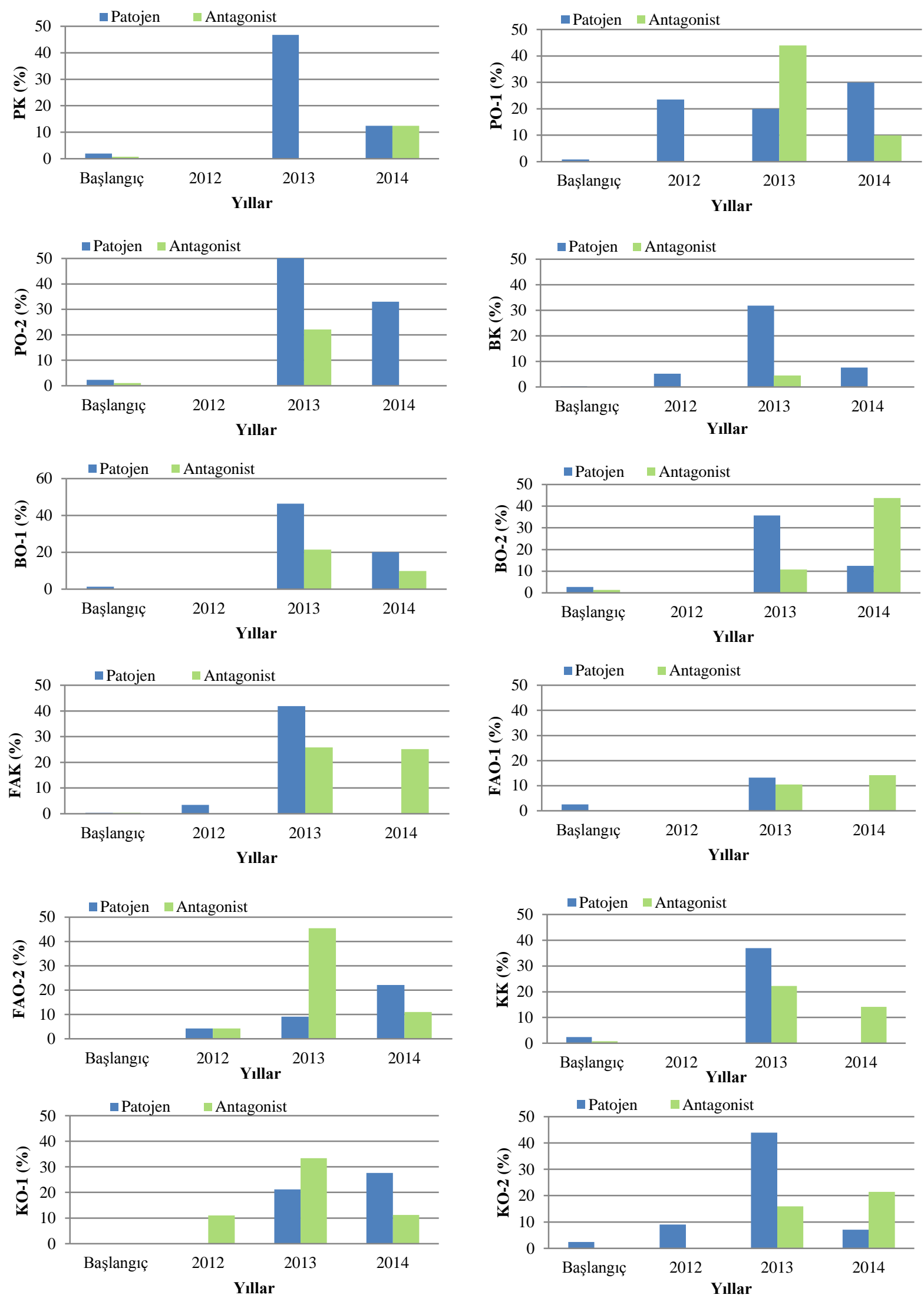

Şekil 5. 2011-2014 yılları arasında organik domates üretimi sonrası farklı ön bitki ve organik gübre uygulamalarına ait parsellerden alınan toprak örneklerindeki patojen ve antagonist mikroorganizma miktarları (\%) 
parsellerde faydalı mikroorganizmaları $\operatorname{artırdığı~}$ belirlenmiştir. Bu çalışmada, Fusarium cinsi içinde en yoğun bulunan türün $F$. oxysporum olduğu saptanmıştır. Ancak, $F$. oxysporum içerisinde de nonpatojenik antagonist izolatlar bulunabilir. Organik yetiştiricilikte organik gübreleme ve ön bitkilerin toprak florasındaki değişimlere etkisinin incelendiği çalışmamız bir ön çalışma niteliğinde olup, bundan sonraki organik tarımla ilgili çalışmalarda topraktaki mikobiyotanın bitkilerdeki hastalıklara etkisi üzerinde detaylı çalışmalar yapılması uygun olacaktır.

\section{Teşekkür}

Desteklerinden dolayı Tarımsal Araştırmalar Genel Müdürlüğü'ne (Proje No: BBOT-11-11) teşekkür ederiz.

\section{Kaynaklar}

Abawi, G.S., Widmer, TL., 2000. Impact of soil health management practices on soil-borne pathogens, nematodes and root dieseases of vegetable crops. Applied Soil Ecology, 15: 37-47.

Anonim, 2010. Gübre denetim rehberi. http://www.tugem.gov.tr/document/gubre_denetim_rehber i.doc. Erişim: 01.12. 2012.

Asan, A., 2004. Check list of Aspergillus and Penicillium species reported from Turkey. Mycotaxon, 89(1): 155157.

Azaz, A.D., Hasenekoğlu, I., 1997. An investigation into the microfungal flora of field soils in the GAP (Southeastern Anatolia Project) Irrigation Area of Harran Plain. Tr. J. of Botany, 21: 165-172.

Barnett, H.L., Hunter Barry, B., 1998. Illustrated Genera of Imperfect Fungi, APS Press. Fourth Edition, p. 218.

Bulluck, L.R., Brosius, M., Evanoylo, G.K., Ristaino, J.B., 2002. Organic and synthetic fertility amendments influence soil microbial, physical and chemical properties on organic and conventional farms. Appl. Soil Ecol., 19: 147-160.

Cheuk, W., Lo, K.V., Coperman, R., Joffie, P., Fraser, B.S., 2005. Disease suppressio on glasshouse tomotoes using plant waste compost. Journal of Environmental Science and Health, 40(30): 449-461.

Cwalina-Ambroziak,,B., Bowszys, T., 2009. Changes in fungal communities in organically fertilized soil. Plant Soil Environ., 55(1): 25-32.

Dhingra, O.D., Sinclair, J.B., 1995. Basic Plant Pathology Methods. CRC Press, Boca Raton.

Dick, M.W., 1990. Keys to Pythium. College of Estate Management, Reading, 64 s, UK.

Duman, $\dot{I}$, Algan, N., 2012. Organik tarımda ekim nöbeti uygulaması. Organik Tarım. (Güncellenmiş 2. Baskı). Ankara.

Erol, F.Y., Tunal1, B., 2009. Determination root and crown rot diseases in tomato growing area of Samsun province. Acta Horticulturae, 808: 65-69.

Eyjolfsdottir, G.G., 1995. Soil fungi isolated from Icelendic farmland. Acta-Botanica-Islandica, 12: 53-62.
Gerlach, W., Nirenberg, H., 1982. The Genus Fusarium-a Pictorial Atlas. Kommissionsverlag Paul Parey, Berlin und Hamburg. pp.406.

Lamey, H.A., Diaper, M.A., 1992. Disease management in home-grown tomatoes. NDSU. www.ag.ndsu.edu.

Lazarovits, G., Hill, J., Patterson, G., Conn, KL., Crum, NS., 2008. Edaphic soil levels of mineral nutrients, $\mathrm{pH}$, organic matter and cationic exchange capacity in the geocaulosphere associated with potato common scab. Phytopathology. 97(9): 1071-1082.

Lessie, J., Summerell, B.A., 2006. The Fusarium. Laboratory Manual. Blackwell Publishing Ltd. Oxford OX4 2DQ, UK. Pp: 278.

Mills, D.J., Hoffman, CB., Teasdale, J.R., 2002. Factor associated with foliar disease of staked fresh tomatoes grown under differing bed strategies. Plant Disease, 86: 356-361.

Oskay, F., 2007. Çankırı İli Eldivan İlçesi Karaçam Ormanı Topraklarındaki Fungal Floranın ve İn-Vitro'da Antagonistik Etkileşimlerinin Belirlenmesi. Ankara Üniversitesi Fen Bilimleri Enstitüsü, Yüksek Lisans Tezi, Ankara.

Serra-Wittling, C., Houot, S., Alabouvette, C., 1996. Increased soil suppressiveness to Fusarium wilt of flex after additional of municipal solid waste compost. Soil Biol. Biochem. 28: 1207-1214.

Singh, C.P., Mishra, M.M., Yadav, K.S., 1980. Solubilization of insoluble phosphates by thermophilic fungi. Ann Microbiol 131: 289-296.

Smith, J.L., Collins, H.P., 2007.Management of organisms and their processes in sols. In soil microbiology, ecology and biochemistry, third ed. Ed. EA Paul, pp. 471-502, Academic Press, Salt Lake City.

Suzuki, C., Takenaka, M., Oka, N., Nagaoka, K., Karasawa, T., 2012. A DGGE analysis shows that crop rotation systems influence the bacterial and fungal communities in soils. Soil Sciene and Plant Nutrition, 58: 288-296.

Swer, H., Dkhar, M.S., Kayang, H., 2011. Fungal population and diversity in organically amended agricultural soils of Meghalaya, India. Journal of Organic Systems, 6(2): 3-12.

Tsror-Lahkim, Barack, R., Sneh, B., 2001. Biological control of black scurf on potato under organic management. Crop Protection, 20: 145-150.

Turhan, G., Turhan, K., Duman, İ., Yolageldi, L., Bozokalfa, K., 2007. Bazı lahana grubu (Cruciferae fam.) sebzelerden sonra yetiştirilen domates, biber ve patlıcan bitkilerinde toprak kaynaklı fungal hastalıkların oluşumu ve bitki gelişim özelliklerinin belirlenmesi. TÜBİTAK, TOVAG 3173 Nolu Proje Kesin Sonuç Raporu.

Wakelin, S.A., Gupta, V.V., Harvey, P.R., Ryder, M.H., 2007. The effect of Penicillium fungi on plant growth and phosphorus mobilization in neutral to alkaline soils from southern Australia. Can J Microbiol, 53: 106-115.

Wu, T., Chellemi, D.O., Graham, J.H., Martin, K.J., Rosskopf, E.N., 2008. Comparison of soil bacterial communities under diverse agricultural land management and crop production practices. Microb. Ecol. 55: 293-310.

Zhou, D., Hyde, K.D., 2002. Host specificity, host-exclucively and host-recurence in sabrobic fungi. Mycological Research, 105: 1449-1457. 